\title{
Travel films, melodrama and the origins of ethnofiction
}

\begin{abstract}
Ompared with the films produced by academic anthropologists, which were modest in both scope and technical complexity, or even with those produced for museums or for empire- and nation-building purposes, the films of ethnographic interest made during the first half of the twentieth century by film-makers working for commercial production companies were generally much more imaginative and technically accomplished. In order to make their films accessible to a popular audience, far from eschewing authorship, as anthropologists of the period sought to do, these commercial film-makers had no hesitation in authoring their films. Ironically, a number of these commercially produced films have been claimed, retrospectively as it were, as masterworks of early ethnographic cinema and are now much more frequently watched and discussed, even in academic contexts, than the films made over the same period according to the self-denying ordinances of more academic ethnographic film-makers.

In this chapter, after a preliminary section discussing the very earliest examples of films concerned with culturally exotic subject matter produced by the Edison and Lumière production companies, I consider how two commercial entertainment genres - the travel film and the melodrama set in an exotic location - constituted the cinematic crucible out of which emerged three films that are often referred to as major milestones in the history of ethnographic film: Grass, In the Land of the Head Hunters and, most important of all, Nanook of the North.
\end{abstract}

\section{EDISON AND LUMIÈRE}

From the earliest days of cinema in the mid-I890s, commercial film producers were actively turning out films about exotic peoples and places, responding to the same strong public demand that at the turn of the twentieth century was also being met, both in Europe and the USA, by Wild West shows, World's Fairs and travel lectures. Initially, these films consisted of no more 
than a single fixed-frame and wide-angle shot taken from a camera set up on a static tripod. They typically lasted less than a minute since that was the maximum duration of the standard roll of film carried by early cameras. Indeed, these films were little more than photographs with the addition of movement and when viewed in a sequence, the effect would not have been dissimilar to watching a series of images in the 'magic lantern' slide shows that these film shows replaced.

But during the course of the first decade of the twentieth century, commercial film-makers realised that if they covered a particular place or event with a systematic series of shots, ideally in combination with some variation in framing and duration, as well as in the placing of the camera, they could then order these shots in such a way as to produce a visual narrative with a beginning, middle and end in which the links between the individual shots could be created or enhanced with the aid of textual intertitles. The technology also improved greatly over this period so that by the end of the decade, the most sophisticated cameras were equipped with magazines that carried sufficient film to shoot for up to six minutes. While most non-fiction films about exotic peoples and places continued to be less than Io minutes long, there were some films that reached 20 minutes or even more.

The first commercial organisation to make a film on a culturally exotic subject appears to have been the company set up by the prolific inventor and entrepreneur Thomas Edison, in order to exploit the Kinetograph moving image camera that he and his associates had developed. This camera was housed in a dedicated studio situated in West Orange, New Jersey, not far from New York. Among the earliest films to be made in this studio were two single-shot films of around 20 seconds featuring a small group of Sioux Indians. One of these films, entitled Buffalo Dance, showed three dancers moving in a circle with two drummers seated behind them, while the other, Sioux Ghost Dance, involved about ten dancers milling back and forth on the small studio stage (figure 2.I, left). ${ }^{1}$

These films were shot on 24 September I894. Given that they involved an exotic cultural subject and pre-date by some six months the chronophotographic images of Africans taken by Félix-Louis Regnault and Charles Comte in Paris, as described in Chapter I, some authors have suggested that these Edison films should be considered the very first ethnographic films. But if they are in any sense ethnographic, they relate more to the ethnography of the end-of-the-century entertainment industry in the USA than to traditional Native American culture. For, as a large sign in the foreground of the Sioux Ghost Dance film makes clear, the dancers were performers from Buffalo Bill Cody's Wild West Show, and, as such, there is no guarantee that all of them were even Sioux. Certainly this Ghost Dance would have had very little to do with the millenarian cult of the same 

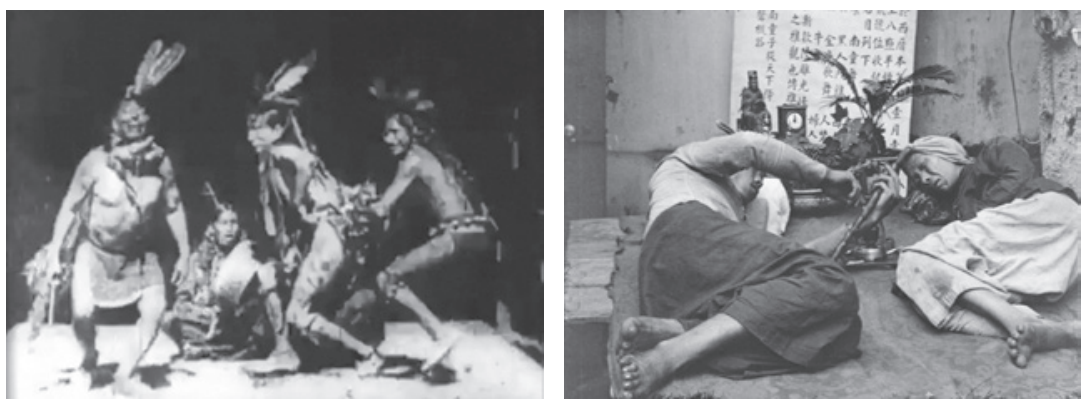

2. I Left, Buffalo Dance, featuring Sioux Indians, shot in the Edison studio, September I894; right, opium smokers in the French colony of Annam (today central Vietnam) filmed by Gabriel Veyre in late I 898 or early I899.

name that had swept through Native American communities in the western states of the USA some five years previously. Buffalo Bill was about to take his show on a European tour and he himself features in two other short films that were shot in the Edison studio on the same day. It seems very likely, then, that all four films were made for promotional purposes related to this imminent tour.

In Europe, the Lumière brothers, Auguste and Louis, after unveiling their cinématographe camera in Lyon in March I895, developed an approach to the taking of 'views' - as single-shot films were then known in France - that was very different from Edison's. The cinématographe was based in part on the technology first developed by Edison, but whereas the Kinetograph was a heavy metal apparatus the size and shape of a small desk, the Lumière camera consisted of a much lighter mechanism housed in a portable wooden box. The Kinetograph was driven by an electrical motor, so had to be close to a power source, while the cinématographe was designed to be cranked by hand. As a result of these differences in technical design, whereas the subjects of Edison films had to be brought to the studio in New Jersey in order to perform in front of the Kinetograph, the Lumière camera operators could take their cinématographe anywhere in the world and film people in their normal everyday surroundings.

By placing an additional light source behind it, the cinématographe could also double as a hand-cranked projector so that the films it produced could then be projected onto a screen in any convenient room. By contrast, Edison intended that the material produced by his Kinetograph camera should be viewed by means of a separate dedicated device which he baptised the 'Kinetoscope'. This consisted of a chest-high wooden box, surmounted by a small portal containing a magnifying glass, which the viewers, one by one, looked down into in order to view the films. Edison believed that this 
single-viewer arrrangement would be the most profitable way to charge for the viewing of films and he set up a series of 'Kinetoscope parlours' across the USA and even in Europe.

However, with the Lumières getting audiences of up to 2,500 people per day for their screenings in Paris by early I896, Edison was rapidly proved wrong and within a very short period, he too was investing in projector technology and sending out cameramen with portable cameras. But although Edison cameramen did film a few culturally exotic sequences around the turn of the century, including some Mexican women washing clothes in I898, some sequences of Eskimo, Native American, Japanese and Spanish performers at the Pan-American Exhibition in Buffalo in I900, and four sequences of different phases of the Snake Dance at the Hopi village of Walpi in I90I, as described in Chapter I, the great majority of the Edison films around this time were either about culturally mainstream North American subjects, or consisted of real or enacted scenes from the SpanishAmerican or Boer wars.

The number of films featuring culturally exotic subject matter produced by the Lumière company was far higher. So too was the technical quality of the films: while the Edison films were often blurred and unstable, the Lumière films were generally sharp and clear. Between I895 and I905, when the company effectively gave up making films, Lumière produced a total of 1422 views. The vast majority of these views are less than a minute long since this was the maximum duration of the I7-metre rolls of film that the cinématographe was designed to take. Just over 800 of the Lumière views were shot in France. Although many of these involve events or self-conscious performances, and include such varied subjects as bull-fights, clown routines, boxing matches, military parades, politicians on walkabout and even some historical and biblical fictions, there are also many views of the routines of everyday life, some of them involving the members of the Lumière family. These everyday subjects include children eating a meal, people boarding a train, a game of cards, women washing clothes in a stream, men repairing a road, horse-drawn carriages passing through a flooded street and, perhaps the most famous Lumière view of all, for being supposedly the very first, the view of the workers leaving the Lumière factory. Taken as a collection, the totality of these views offer a remarkable ethnographic snapshot of France at the turn of the twentieth century. ${ }^{2}$

Most of the remaining Lumière views were shot elsewhere in Europe - Italy and Britain being the principal alternative locations. But around 200 Lumière views featured non-European subjects. At first, Lumière cameramen confined themselves to filming performers at the many exotic fairs then travelling through Europe, including Javanese jugglers in London and an Ashanti village and a group of Sinhalese dancers in Lyon, where the Lumière company was based. But before long, Lumière operators were 
travelling across the globe. One of most energetic was Gabriel Veyre who, between August I896 and March I900, made a series of visits to Mexico, Japan, and the French colonies in Indochina (figure 2. I, right). The Lumière catalogue contains details of around sixty views that Veyre shot in the course of these trips. On his way to Japan, he travelled through Canada and on 2 or 3 September I898, he shot Danse indienne, a view of three men engaged in a dance on the Mohawk reservation at Kahnawake, across the St. Lawrence river from Montreal. This is one of the first moving image sequences taken of a North American First Nations people, preceded possibly only by the now seemingly lost footage shot some ten days before, on 22 August I898, by Burton Holmes's cameraman, Oscar Depue, in the Hopi village of Orayvi, as described in Chapter I. ${ }^{3}$

By the end of I90I, the Lumière company had shot at least I300 views (i.e. over 90 per cent of its total output). Although it continued to make films sporadically over the next few years, the Lumière company had given up all film-making by I905, at the latest, in order to dedicate itself to the development of colour photographic plates and, over the subsequent years, a diverse series of other inventions, including the 'periphote', a 360-degree photographic camera, membranes for loudspeakers, a prosthetic hand and medical dressings for war wounds. But in any case, by this time, the newsreel agencies Gaumont and Pathé had already taken over from the Lumière company as the most active producers in France of films on culturally exotic subjects.

\section{EXotic REPORTAGE AND TRAVELOGUES}

According to the French cinema writer, Pierre Leprohon, the cameramen who worked for Gaumont and Pathe in the early years were mostly freelancers who were provided with equipment by the agencies but had to supply their own film. They were then paid for the exposed film that they sent back to the agencies, though there was a significant difference in the rate of pay depending on where the material had been shot: 7 francs per metre of film shot in France, Io or even Is francs per metre shot abroad. Unsuprisingly, many operators went abroad, initially to the French colonies in North Africa, but soon to many other parts of the world. Adapting a usage of Leprohon, I refer to these films shot abroad by French newsreel operators as 'exotic reportage'. 4

Early twentieth-century French audiences appear to have had a great appetite for material of this kind since a large number of films of exotic reportage were produced during this period. These works were typically considerably longer than the 50-second single-shot views produced by the Lumière operators, though the duration of the great majority was still less 
than Io minutes. They were also very much more sophisticated, both technically and as filmic texts, particularly with regard to their narrative structuring. Even so, the operators who made these films were generally regarded as no more than technicians and their works often do not even bear their names, or if they do, it may be only their family name. And yet the aesthetic quality of their work in a cinematographic sense was often very high, while their ethnographic observation, though presumably entirely untutored, could be remarkably acute. ${ }^{5}$

A review of this vast body of work is far beyond the scope of this chapter. Instead I consider only one example, which will have to stand in a synecdochic manner for the whole genre of film that I refer to as 'exotic reportage'. Not only is this example particularly well made, but it is also readily viewable on the British Film Institute (BFI) website. It was released in I909 by Pathé Frères, but testifying to the international nature of Pathé's distribution network, the BFI version carries a German title, Delhi: Die Grosse Stadt in Vorderindien. Moreover, a very brief logo at the end of the film suggests that the film may have been produced by Luca Comerio, a production company based in Milan. However, nowhere on the film is there an indication of the name of the operator. But whoever did shoot the film clearly knew what they were doing.

Notwithstanding the title, which translates as Delhi: Great Capital of India, the film does not offer a general portrait of the city, but rather very specifically concerns the major Muslim festival of Muharram as celebrated at the Jamia Masjid, the Great Mosque of the city. This festival is Shiite in origin and evokes the martyrdom of Hassan and Husayn, the grandsons of the Prophet. The film is only 4 minutes long, but covers considerable ground in a highly efficient manner, using a cinematographic language that is readily recognisable more than a century later and which had clearly been carefully thought through in advance. The general quality of the film has also been enhanced by stencil-colouring.

Following a brief establishment shot over the mosque, seemingly taken from one of its minarets, there is then a cut to a series of shots of street performers entertaining the crowd attending the festival. Next comes the parading of models of the tombs of Hassan and Husayn and a river of worshippers flows past the well-positioned camera. Although they are very varied in age and dress, we note that all the worshippers are men; on their shoulders, the models of the tombs take an extraordinary range of different forms.

The second half of the film consists of a series of shots taken in and around the mosque. First, there is an establishing wide shot of the courtyard of the mosque taken from a distant elevated position, with a pool in the foreground where worshippers are carrying out their ablutions. There is then a cut to a much closer shot of the pool, indicating that the operator 
may have changed the lens at that point (it would be another fifty years before the zoom was invented). A third shot, taken from the edge of the pool, at 45 degrees to the line of the previous two shots, offers an intimate view of the worshippers as they wash they feet and arms, and also their teeth. Next we see the worshippers praying in front of the mosque itself: again this starts with a distant shot from an elevated position before cutting to a closer shot of the same scene. The final image, again from afar but this time from outside the mosque, consists of a ravishing shot of the worshippers descending the stairs in front of the mosque as they leave. This shot has a strongly valedictory feel to it and brings the film to an end in a very effective manner (figure 2.2).

This brief film is particularly interesting not only for its cinematographic sophistication but also as a historical as well as an ethnographic document. For, at the time it was made, despite its Shiite origins, many different groups in Delhi would have participated in the Muharram festival - neighbourhood organisations of various kinds, caste representatives, craft guilds, even associations of prostitutes. This would explain why the models of the tombs being carried by the worshippers take such a variety of forms, with some looking more like Hindu temples than mosques. In fact, it is quite probable that there would have been no Shiite participation at all in this event, since not only is Delhi predominantly a Sunni city, but the Jamia Majsid is its principal Sunni mosque. Certainly, the presence of jugglers and acrobats such as we see in the early part of the film would have been incompatible with the original Shiite conception of the fesival, which is as a symbolic funeral procession for the martyrs Hassan and Husayn and as such, as an event that should be conducted in the most solemn manner. Today, as the division between Shiite and Sunni has become more sharply demarcated in Islam generally, Muharram is no longer celebrated in Delhi since it has come to be seen as a festival that belongs exclusively to Shiites. ${ }^{6}$

After the First World War, both Pathé and Gaumont developed their reportage film repertoire and began to produce more extended educational films, often in collaboration with academic advisers. Pathé also collaborated with scientific expeditions, including with the American Museum of Natural History expeditions to Central Asia in the years I92 I-30. Although primarily dedicated to zoological and archaeological matters, the films that arose from this collaboration also included a film about contemporary Mongol life and another about 'Peking' as Beijing was then known. In a similar manner, in I928-29, Pathé collaborated with the Department of Anthropology at Harvard to make the Pathé Science series, which consisted of three short films: one about life in Java, another about Bedouin herders in the Arabian desert and the third about Mongol herders in the Gobi desert. ${ }^{7}$

While all these Gaumont and Pathé films contain material of an ethnographic character, one of the most accessible forms of exotic reportage is 

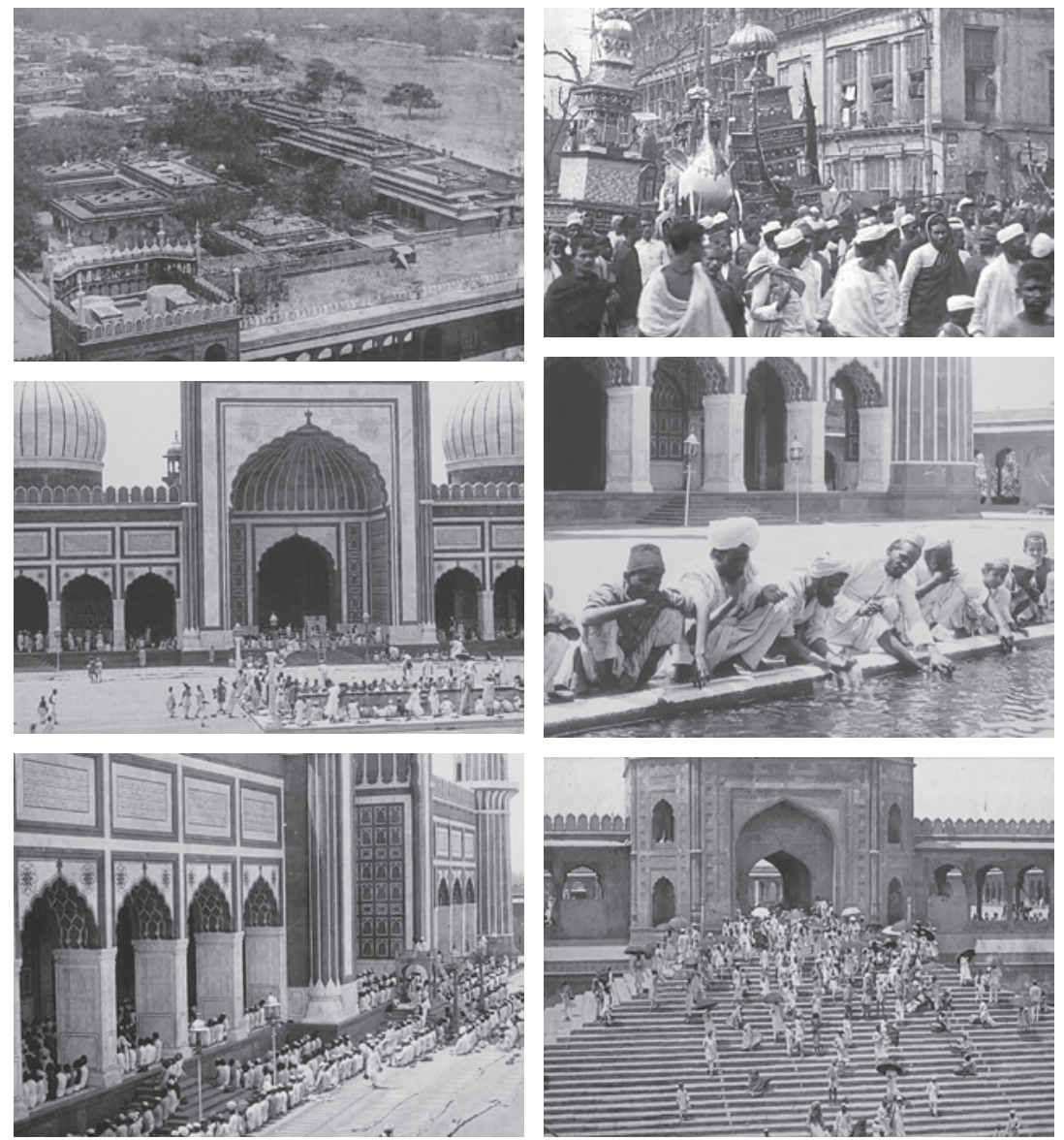

2.2 Delhi, Great Capital of India (I909). In four minutes, a narrative is economically deployed: above, an establishing overview before passing to the procession in the street; middle, a distant shot of the inner court of the mosque gives way to a midshot of the faithful performing ablutions; below, the faithful are seen praying before they finally leave in a classical closure shot.

the so-called Pathé-Baby series, launched in the I922. This was distributed on $9.5 \mathrm{~mm}$ film and was aimed at the domestic market. The films were typically no more than $I_{1}^{1} / 2$ minutes long and were usually abridged versions of reportage films that had previously been distributed through cinemas, sometimes many years previously. While some of the films were Pathés own productions, others were bought in. The series covered every genre and every subject, from films about physics to cartoons, with drama, comedy, religious edification and sports films in between. The I93 I Pathé-Baby catalogue covers a dozen such categories, but the first two - 'Voyages' and 
'Usages and Customs' - contain a considerable number of films of potential ethnographic interest, including some unattributed extracts from Nanook of the North. Many of these Pathé-Baby films are now readily available on the Web. ${ }^{8}$

In the USA, the most prevalent form of commercial film-making to feature exotic subject matter in the period prior to the Second World War was the genre that came to be known as the 'travelogue'. Although the distinction may often have been blurred in practice, the travelogue may be differentiated from the expedition films of the interwar period such as those discussed in Chapter I, on the grounds that whereas the latter category consisted of films produced as a by-product of journeys that had some other purpose (exploration, the collection of zoological specimens, archaeological research, sometimes merely big game hunting), in the case of the travelogue, the making of the film was itself the primary purpose of the journey.

The origins of the travelogue lay in the phenomenon of the travel lecture, which by the late nineteenth century was a hugely popular form of public entertainment in the USA, capable of generating large returns at the box office. Originally, travel lecturers illustrated their talks with 'magic lantern' slides of scenes from around the world, but by the end of the I 890 os they had already begun to use film as well. These film materials would often be specifically commissioned by the lecturers, who would sometimes accompany the cameramen on their expeditions to direct their activities. By the I920s, the lecturers had begun to appear in front of the lens on location and the fully fledged travelogue format had emerged. ${ }^{9}$

Although travelogue film-makers would often seek to give their films an aura of academic respectability by seeking the endorsement of leading museums, professional associations or universities, the genre was geared from the start towards providing popular entertainment. Whereas in the French reportage film, the film-maker was often not even named, in the travelogue the travel lecturer, now transformed into celebrity traveller, was often the centrepiece of the show. Prior to the development of soundtracks in the I93Os, the commentary of the traveller-lecturer on the subject matter of the film would be made through the extensive use of intertitles. Whereas in the French reportage film, intertitles typically provided no more than low-key factual information, the travelogue intertitle aimed to entertain the audience by mixing the provision of information with some kind of jocose observation. As the joke was often at the expense of the subjects, at least in the films shot in Africa and Asia, today these intertitles often seem at best ethnocentric, and at worst, crassly racist or sexist (figure 2.3).

If the travelogue differed from the French reportage film, it was even further from the modest descriptive films produced by academic anthropologists prior to the Second World War. Whereas anthropologists were often moved to make their films by a perceived need to record the last vestiges 

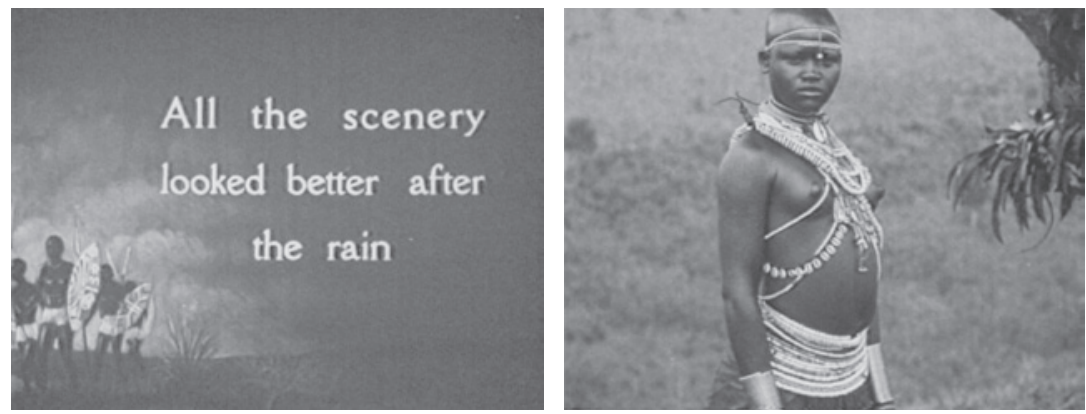

2.3 Simba, King of the Beasts (1928), directed by Martin and Osa Johnson. The jocose intertitle on the left immediately precedes the image on the right, which shows a young Samburu of northern Kenya.

of particular cultural phenomena before they disappeared, the makers of travelogues liked to emphasise rather that their films offered records of 'first contacts' - often in direct contradiction to the evidence offered in the actual films. ${ }^{10}$ An even greater point of contrast was that while academic anthropologists sought to avoid any kind of authorship and to use the camera simply as a recording instrument, the makers of travelogues had no reservations about trumpeting their authorship and using every possible cinematographic means to make their films more entertaining.

As well as the jocose intertitles, these means included intervening directly in the lives of the subject to produce comedic effects. This is exemplified by a sequence shot in I932, which is now readily available on the Web. This shows Osa Johnson, who, with her husband Martin, was one of the leading travelogue film-makers of the era, encouraging a group of Mbuti 'pygmies' of the Ituri rainforest in Central Africa to dance with her to the sound of jazz music playing on a wind-up gramophone. Although the sequence is in many ways grotesque, covered as it is by an execrably racist commentary and laying out the disparity in power between film-maker and subjects in the most cringingly blatant way, it is at the same time intriguing that the Mbuti do instantly know how to swing. ${ }^{11}$

Although the classical US travelogues may be mined for the occasional vein of ethnographic interest such as this, films in this genre are usually so submerged beneath a layer of artifice and colonial racist bluster that they are of little value. Yet, as an exception to the general rule, there is one particular film that emerged directly from the cinematic environment of the self-aggrandising travelogue which has often been identified as an important milestone in the development of English-language ethnographic film. This is Grass - A Nation's Battle for Life, released in 1925 and directed by Merian C. Cooper and Ernest B. Schoedsack, who a few years later would again combine forces to achieve fame and fortune in Hollywood as 
the directors of King Kong. Given the prominence of Grass in the visual anthropology literature, I shall now consider it at some length.

\section{The travelogue as proto-ethnographic Film: THE CASE OF GRASS}

Cooper and Schoedsack met in Europe in the aftermath of the First World War, when both were involved in the armed conflict between Poland and the fledgling Soviet Union. Cooper was a pilot with the US Army, while Schoedsack was a combat cinematographer. In making Grass, they were accompanied by Marguerite Harrison, the daughter of a wealthy US shipping magnate, who had worked in Germany during the war, and later in Moscow, ostensibly as a journalist, but also as a spy for US military intelligence. While in Moscow, she had smuggled blankets and food into the Red Army camp where Cooper had been imprisoned after being shot down, eventually meeting up with him in Warsaw in 1922. At first, Schoedsack was against her involvement in the film, but he later relented, probably not unrelated to the fact that she put up half the budget. The other half was jointly contributed by Cooper and Schoedsack himself, while Schoedsack also contributed the Debrie camera on which the film was shot. ${ }^{12}$

Initially, the three of them spent some time travelling through Turkey and Iraq in search of a suitable subject, with Schoedsack shooting footage along the way to sell to newsreel agencies. This footage included memorable scenes of a dancing bear in a Kurdish village in Turkey, the hunting of a long-horned wild goat in the Taurus mountains on the border with Syria, and an encounter with an Iraqi desert police detachment mounted on camels. Eventually, however, the trio reached what was then Persia and is now Iran, where they met with Sir Arnold Wilson, chairman of the Anglo-Persian Oil Company, and Gertrude Bell, the celebrated Near East specialist.

It was Wilson who suggested to them that they should film the remarkable annual migration of the Bakhtiari sheep pastoralists to their summer pastures in the Zagros mountains, near Isfahan. Wilson knew about this migration because Bakhtiari territory fell within the drilling concession that his company had been awarded by the Persian government. Wilson also had the influence to get the film-makers the necessary permits, both from local government officials and from the Il-Khani, the Bakhtiari paramount leader. Il-Khani in turn provided them with an introduction to Haidar Kahn, chief of the Baba Ahmadi, the subgroup of Bakhtiari who would actually feature in the film. Accordingly, the film-makers made their way to Haidar Kahn's village and after a brief stopover there, set out, in April I924, to accompany the Baba Ahmadi on their gruelling 48-day 'battle for life', as the subtitle of the film would later have it. 
However, in the editing down of the I4 hours of rushes to the 7I-minute final film, there was no reference to the film-makers' initial meanderings, nor the circumstances through which they finally hit on the topic of Bakhtiari migration. Instead, in accordance with a classic travelogue trope, Grass is presented as a single unitary journey in search of a 'Forgotten People'. Moreover, in being a journey eastwards, contrary to the direction in which the film-makers own 'forefathers, the Aryans of old' had migrated in 'conquest of the earth', it is also construed as being a journey back in time in search of the film-makers' very own 'brothers still living in the cradle of the race'. The point is reinforced by a dramatic, if stereotypical, opening shot of a long line of camels moving from left to right on the horizon, as if it were from west to east on a conventional map.

The three travellers themselves are then introduced, looking elegant and relaxed in the explorer-chic clothing of the day, a style that would later be imitated in the Indiana Jones movies. Although these portraits are presented with a boulder in the background, as if they had been filmed on location, they were actually shot after the film-makers had returned to the USA, in the Paramount Astoria Studios in New York. Thereafter, the two men are not seen again in the film. Although Marguerite Harrison appears prominently in the sequences prior to the arrival at the Bakhtiari village, providing the 'I-was-there' authority typical of the travelogue genre, during the migration itself, she is only ever seen fleetingly and from afar. ${ }^{13}$

The first third of the film is presented as a record of the film-makers' journey across Turkey and Iraq and into Iran in search of the 'Forgotten People': this allows them to present the disparate material shot during the initial exploratory phase of their project in a coherent and cumulative manner. But following the encounter with the Bahktiari, there is a change of gear, as two new characters are introduced: Haidar Kahn, and his 9-year-old son, Lufta. Haidar is described as the chief of a 'tribe' whose way of life has not changed for 3,00o years. On account of their light-coloured skin, they are identified as 'Aryans', and therefore, by implication, as the ancestors for whom the film-makers have been searching. The Islamic title of Haidar Khan, clearly belying the trope of three millennia of unchanged tradition, is not a matter on which the film chooses to dwell.

Haidar is then shown gathering his lieutenants around him and announcing that it is time for the Baba Ahmadi to pitch their tents and head even further east, up into the mountains in search of fresh pastures. Rather than following the journey of the film-makers, the narrative thread of the film then becomes the journey of Haidar, Lufta and, supposedly, 25,000 of their fellow Bakhtiari, not to mention some I25,000 animals (figure 2.4). ${ }^{14}$

In purely cinematographic terms, some of the sequences of this part of the film are truly remarkable, none more so than the sequence of the 

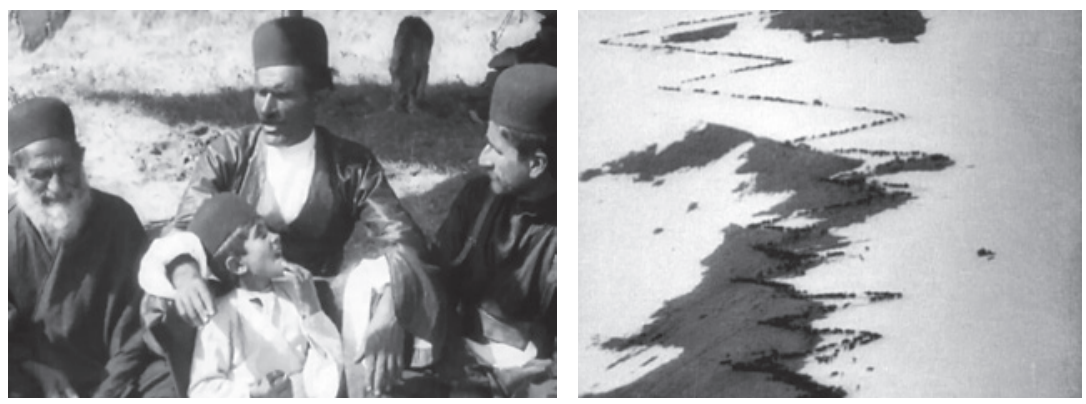

2.4 Grass - A Nation's Battle for Life (I925). The story of Bakhtiari migration is built around the headman Haidar Kahn and his son Lufta, left; but during the epic journey itself, right, they are glimpsed only rarely.

seemingly endless columns of Bakhtiari trudging barefoot through the snow-covered Zardeh Kuh mountain pass, some carrying their animals. Also impressive are the shots of the Bakhtiari crossing the glacial Karun river 'over six days and nights' on rafts consisting of no more than inflated sheepskins. Although there are some brief glimpses of Harrison and a stream of alternately dramatising or self-consciously jocose intertitles of the kind that were typical of the travelogue genre, the authorial presence of the film-makers is muted - it is rather the Bahktiari who are the heroes of this part of the film. ${ }^{15}$

The journey ends with Haidar in his tent, with Lufta at his side, puffing on his pipe and looking contentedly at the grazing sheep. Though the characterisation of Haidar and Lufta in the film has been slight and romantically stereotypical, and we only see rare glimpses of them during the migration; this technique of building a narrative around the experiences of a limited number of principal characters is one that would later be much developed within the genre of ethnographic documentary. ${ }^{16}$

However, the happy scene of Haidar gazing at the sheep is not quite the end of the film. For, in a bizarre coda, the travelogue format returns in full force as we are shown a document, formally witnessed by the American vice-consul in Tehran, who, we are informed, was soon to be murdered in the street. This last detail, although completely irrelevant to the principal narrative of the film, adds an additional aura of mystery and danger to the content of the document witnessed by the unfortunate vice-consul. This purports to be a statement by Haidar Khan and Amir Jang, 'prince of the Bahktiari', to the effect that the three travellers were the first outsiders to accompany the Bahktiari on their perilous migration through the Zardah Kuh pass. By this means, we are reminded that it is 
not, after all, the Bahktiari, but rather the travellers who, in the classic manner of the travelogue, are the real heroes of this film.

\section{Melodrama And THe DOCUMentaire ROMANCÉ: THE CASE of IN THE LAND OF THE HEAD Hunters}

It was not only through travelogues and other variants on the travel film format that commercial film producers in the early twentieth century sought to satisify the great public interest in culturally exotic ways of life: early fiction films would also often be set in exotic locations with a melodramatic Western story grafted onto an idealised interpretation of local cultural realities.

In the USA, prior to the First World War, at least two film versions were made of The Song of Hiawatha, Henry Wadsworth Longfellow's poetic paean to Native American life immediately prior to the arrival of the Whites, first published in I855. The first of these Hiawatha films, released in I908, was made by the Baptist-minister-turned-film-maker, Joseph K. Dixon for the Philadelphia department store magnate, John Rodman Wanamaker, while the second was produced in collaboration with the American Museum of Natural History by Frank E. Moore and released in I9I3. In Canada, no fewer than three films about a Hiawatha pageant were made over the same period. $^{17}$

The influential early Hollywood director, D. W. Griffith, was but one of many who around this time cut their directorial teeth making films in culturally exotic settings. One of his very first films was The Zulu's Heart, a Io-minute two-reel 'short' made for the Biograph company in I908 which featured 'blacked up' White actors. This told the supposedly heart-rending story of a Zulu chief who after his own child dies of fever is then moved to spare a little Boer girl captured in a raid. The following year, Griffith made at least three shorts in what were purportedly North American Indian settings, The Mended Lute, Comata the Sioux and The Redman's View, but again with White actors playing the principal indigenous parts and with similarly melodramatic storylines. ${ }^{18}$

A similar series of films was made around the same time by Gaston Méliès, the elder brother of Georges, the well-known early French director of fantasy films. Gaston's films were produced by Star Film, a subsidiary company that Georges had set up in the USA in I904 to protect the copyright of his films. After managing his brother's business in the USA for a while, Gaston set off in July I9I2 to travel around the Pacific and East Asia determined to make a series of his own films in exotic settings. Some of these were descriptive films of documentation, while others were examples of the genre known in France as 'documentaire romancé, a term that could be literally translated as 'storified documentary'. Among the Méliès documentaires romancés were 
two shot in Tahiti and two in New Zealand. Like the Griffith films, these were all short two-reelers based on melodramatic storylines. All of them involved conflicts connected with affairs of the heart, sometimes in an exclusively indigenous setting, but mostly across a European-indigenous fault line. Sadly, all but one of them, Loved by a Maori Chieftess, released in the USA in I9I3, appear to be lost. ${ }^{19}$

This genre of melodrama played out in an idealised exotic cultural setting also includes another film from this period which, like Grass, has often been claimed in retrospect as a major landmark in the development of Englishlanguage ethnographic film - even to the extent of being included in the collection of only eight supposedly 'ethnographic' films in National Film Registry of the US Library of Congress. This is In the Land of the Head Hunters, first released in I9I4. The director and producer was Edward S. Curtis, already well known in the USA at that time for his romantic photographs of Native Americans in traditional dress from which almost all evidence of their contemporary situation as subjugated peoples had been excluded. In effect, Head Hunters represented an attempt to employ essentially the same methods to the production of a moving image film. ${ }^{20}$

Head Hunters was mostly shot on Deer Island, which lies a few hundred metres off the northeastern shore of the very much bigger Vancouver Island, on the Pacific coast of Canada. Although they are not specifically named at any point in the film, it was made with the active participation of the people who were known for many years in the anthropological literature as the Kwakiutl, but who are now more generally referred to as the Kwakwaka ${ }^{\prime} w a k w .{ }^{21}$ Curtis would sometimes claim that the film was based on 'tribal lore', but although the Kwakwaka $\underline{a}$ 'wakw may have had some input into the storyline, it is primarily constructed around the same 'love triangle' trope found in many of the melodramas in indigenous settings produced in the period immediately prior to the First World War.

In this case, the triangle involves the young warrior Motana, the beautiful young maiden Naida, and the Evil Sorcerer to whom, against her will, Naida has been betrothed. After seeing her in a vision quest, Motana successfully woos Naida and asks her father, Waket, for her hand in marriage. But Waket says that he will only consent if he is brought the head of the Sorcerer as a wedding offering. Motana's father, Kenada, then raids the Sorcerer's village, returns with his head and demands that the wedding feast take place (figure 2.5). However, when Motana and Naida return to Kenada's village after the wedding, it is attacked and burnt to the ground by Yaklus, the fearsome brother of the Sorcerer who is enraged at his beheading. Kenada himself is killed, while Motana is left for dead and Naida is carried off by Yaklus.

There then follows the most elaborate ceremonial sequence in the film as Yaklus celebrates his victory back at his own village. This includes dances of the kind that were traditionally performed during Kwakwaka ${ }^{\prime} w a k w$ 

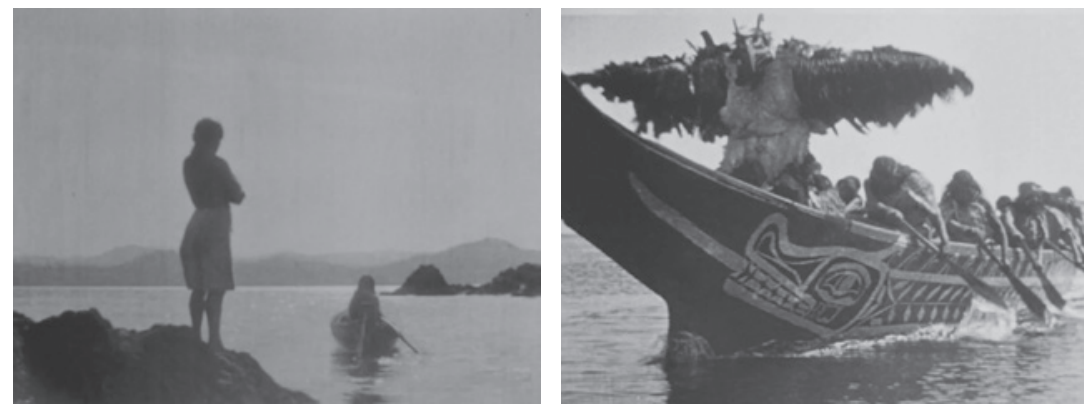

2.5 In the Land of the Head Hunters (I9I4). Left, Motana watches Naida depart after he has given her a token of his love; right, later, Motana's party arrives in style for the wedding feast, with the Thunderbird in the prow of one of three highly decorated canoes.

winter ceremonies and which feature dancers wearing a range of magnificent wooden masks. Naida is obliged to dance before Yaklus, who, entranced by her beauty, decides to spare her life and keep her as his slave. But in the night, Motana, who has been resuscitated by a 'Medicine Man', sneaks into Yaklus's house and carries Naida off in his canoe. He is pursued by Yaklus and his warriors, but as the two canoes pass through a surging gorge, Yaklus's canoe capsizes and he is drowned. The final sequence shows Motana and Naida safe in their canoe, followed by a sunset bringing the film to an end.

This was not the first film-making project that Curtis had undertaken: he had previously shot some footage among the Hopi and also the Navajo in 1904 or 1906 . He even appears to have previously shot some footage among the Kwakwaka ${ }^{\prime} w a k w$ in I9Io or I9II. ${ }^{22}$ But this was an altogether more ambitious work. Although Head Hunters had explicitly commercial objectives - Curtis hoped to raise money to support the continuation of his monumental photographic encylopaedia, The North American Indian - he aimed at the same time to achieve a high degree of cultural authenticity.

To this end, he recruited a self-trained ethnologist and former journalist, William Myers, who had worked as his assistant for many years on his earlier photographic expeditions. More importantly, he also engaged George Hunt, a local man of mixed British and Tlingit descent, who had married into the Kwakwaka $\underline{a}$ 'wakw. Hunt had been acting as Franz Boas's principal informant since I888, some two years after the latter began his research on the Pacific Coast, and he would continue to act as such after Head Hunters was completed, until his death in I933. In the case of Head Hunters, however, Hunt was clearly more than just an informant: a well-known photograph of the production shows him standing with megaphone in hand, apparently directing the action, while Curtis busies himself with the camera. ${ }^{23}$ 
In contrast to the cast of the melodramas of D. W. Griffith, the cast of Head Hunters was entirely indigenous, mostly Kwakwaka wakw. The actor who played Motana was George Hunt's son, Stanley. A number of Hunt's other relatives also had named roles in the film. As many of the leading actors were from noble lineages, the process of casting was a particularly delicate matter since the Kwakwaka 'wakw have strict rules about the behaviour appropriate to particular statuses: three different actresses were required to play the female lead, Naida, in part because of a mismatch between the actions called for by the script (for example, paddling a canoe) and the behaviour deemed appropriate to the individuals of elevated status who were supposed to be playing the role. George Hunt would surely have been of great assistance to Curtis in navigating his way through these sensitivities.

The film was set in some indeterminate period in the past: an early working title was 'In the Days of Vancouver', which would have made the setting the I790s, the period when the British naval officer, Captain George Vancouver, charted the waters of the North Pacific Coast. In effect then, the actors were supposed to be playing their own ancestors. But by I9I4, most Kwakwaka 'wakw had abandoned traditional forms of dress and hair styling, so Curtis commissioned a number of local people, notably George Hunt's wife, Francine, to manufacture both ceremonial regalia and everyday clothing appropriate to the period. Much of this clothing was manufactured out of raffia, which on film reads much like the traditional cedar bark cloth. The actors were also supplied with long black wigs and nose ornaments, while many of the elaborate painted wooden masks that feature strongly in the film were purchased or carved specially for it. The increasingly obsolete massive dugout canoes that also play an important part in the film were repaired and repainted, and a series of totem poles and facades imitating traditional house frontages were erected on Deer Island, which is directly opposite Tsaxis (Fort Rupert) where the production team was based. The principal action of the film takes place in this reconstructed village set or on the beach nearby.

One of the most significant aspects of this filmic recreation of the past was that it featured certain dances and other practices that had traditionally formed part of the competitive gift-giving ceremonies known as the 'potlatch', for which the peoples of the North Pacific coast are renowned. In these ceremonies, the chief hosting the event would compete with visiting chiefs in demonstrating his wealth and generosity, and hence his power, not merely by giving away large quantities of gifts and prestigious ceremonial titles but also by destroying certain valuable commodities. But at the insistence of government agents, who considered it a highly wasteful custom, and missionaries who suspected it of invoking the devil, the potlatch had been outlawed in Canada since the Indian Act of I884 (and would continue to be outlawed until I95I). 
In Head Hunters, the potlatch is not specifically referred to, but the wedding feast is, in effect, more of a potlatch than a wedding in that it consists primarily of a sequence of Motana's father, Kenada, giving away a pile of blankets and bark clothing, which is then followed by another sequence showing the competitive consumption of the much valued candlefish oil. The bride and groom, meanwhile, are nowhere to be seen. Potlatch-related dances feature both in this scene and elsewhere in the film, though they are sometimes interspersed with dances invented specifically for the film. Given the political circumstances, the opportunity to perform these otherwise prohibited dances, even if in a modified form, may have been one of the main reasons why many Kwakwaka ${ }^{\prime}$ wakw were pleased to be involved in the production.

If some aspects of the film represented a partial compromise on the ethnographic reality of traditional Kwakwaka ${ }^{\prime}$ wakw society, a few were completely alien. One of the most frequently remarked upon concerns a scene in which Motana goes on a whale hunt, supposedly as an aspect of his initiation into manhood. In fact, the Kwakwaka 'wakw never hunted whales: this was a practice confined to the indigenous groups living on the Pacific coast of Vancouver Island, such as the Nuu-chah-nulth (formerly known as the Nootka) and the Ditidaht. In order to shoot this scene, Curtis had to rent a whale carcass from a commercial whaling company. Not surprisingly, the scene is rather underwhelming and mostly consists merely of Motana standing on the carcass, with some static canoes in the background.

There is a certain tendency to assume that because Curtis was a highly gifted photographer, he was also an accomplished film-maker. Certainly no one could fault Head Hunters for the time and effort committed to the painstaking recreation of traditional Kwakwaka ${ }^{\prime}$ 'wakw practices and artefacts, and it contains some truly wonderful individual sequences of ceremonial performance. Perhaps the most impressive of these is the sequence that shows three great canoes arriving for the wedding feast while on their prows, the extravagantly masked and costumed figures of the the Grizzly Bear, the Thunderbird and the Wasp are seen dancing ecstatically, arms outstretched. There are also a number of sequences where the physical demands of the particular location appear to have required Curtis to come up with some visually dynamic shots - for example, when the camera is mounted within a canoe as a raiding party approaches the shore or when Motana and Naida escape along the beach, running towards and past the camera. But for much of the film, wide shot follows unimaginatively upon wide shot, even if in terms of content and composition the quality of those individual shots is often high. ${ }^{24}$

Also, even when considered entirely on its own terms as a melodrama, Head Hunters is somewhat confused from a narratological point of view, with a number of scenes that obstruct rather than advance the story, and 
which appear be there entirely for their spectacular quality. The weighting of the major ceremonial scenes is particularly strange:Yaklus the villain gets to host the most elaborate ceremony, while the wedding feast, after a big build-up, does not feature any sort of wedding. The general sense of confusion is exacerbated by the fact that Curtis used the same set for both warring villages and also the same canoes. While several actors played a single role, as in the case of Naida, in other cases, a single actor played several roles: for example, the actor who played the 'bad' chief Yaklus, also played the 'good' chief Waket, Naida's father. It is therefore often difficult to work out who is who and where one is at any given moment in the film. ${ }^{25}$

Indeed, Curtis appears to have had only a limited grasp of film grammar. Apart from the series of portraits introducing the leading characters with which the film opens (itself more of a theatrical than a cinematic device), close-ups of individuals are relatively few. There is an intriguing close-up of the dastardly Sorcerer when he first appears, emerging from the undergrowth, peering suspiciously. But there is no equivalent shot of the leading 'good' characters. The closest we get is a shot of Motana mugging for the camera from inside the ethnographically inappropriate whale carcass. ${ }^{26}$ In the midst of the marriage-cum-potlatch ceremony is a wide shot of men employing extraordinarily large ladles to serve out the candlefish oil that is followed by a close-up shot of one of the visiting chiefs drinking the oil. This works very well but it is the exception to the general rule: for the most part, the ceremonies are shot as a series of wide-angle tableaux, without being leavened by any engaging shots of detail.

Nor did Curtis appear to have any idea how to use anticipatory intertitles to create dramatic tension or interest (this would later turn out to be one of Robert Flaherty's great skills); on the contrary, his intertitles tell us what we are going to see and then we see it. Long before we see Yaklus floating in the sea, apparently drowned, we have already been told in an intertitle that this is going to happen, so we already know what the outcome of the climactic final canoe chase is going to be. While it is true that the grammar of film-making was still being worked out in I9I4, Curtis's visual story-telling skills were certainly not as developed as those of some of his contemporaries, including the anonymous French newsreel cinematographers alluded to above.

These cinematographic weaknesses of Head Hunters may have been a factor contributing to the commercial failure of the film, notwithstanding the care lavished on the reconstructions, not to speak of the large budget. At the time of the film's release, in December I9I4, some six months after the end of the shoot, it was reported in the press to have cost 75,000 dollars to make, the equivalent of almost 2 million dollars today. Perhaps overinfluenced by Curtis's already established reputation as a photographer, most cinema critics gave it highly positive reviews. But the public voted with their feet and stayed away. After short runs at prestigious theatres in Seattle 
and New York, Head Hunters remained in circulation for a couple of years in the USA but its distribution was limited. Owing to the collapse of the film's distributor, it never reached Europe, where it might have done well, particularly in France.

In I924, in a state of financial embarassment, Curtis offered everything that he still had of the film, including a copy of the negative and his master positive, to the AMNH for I,500 dollars, at the same time renouncing all his rights. The AMNH curator Pliny Goddard consulted Franz Boas about the offer and the latter advised that while the melodramatic story could be dismissed as entirely inauthentic, the film would be valuable as a record of Kwakwaka 'wakw ceremonies. Goddard therefore beat the price down to I, ooo dollars (less than I5,000 dollars today), which Curtis found himself obliged to accept. Sadly, however, the AMNH does not appear to have done anything with this print and there is no record of what happened to it. ${ }^{27}$

After its failure at the box office, Head Hunters was lost for many years. Then, in I947, an eccentric film collector donated a copy of the film, seemingly recovered from a skip behind a cinema in Chicago, to The Field Museum of Natural History in the same city. By this time, only about two-thirds of the film's original 90-minute duration was left, and much of that was damaged due to decomposition of the $35 \mathrm{~mm}$ nitrate stock. In order to preserve it from further deterioration, this remnant was transferred to I6 $\mathrm{mm}$ safety stock by The Field Museum technicians. This ensured its survival, but resulted in a further degradation of the image quality. As it would have constituted a fire risk, the original $35 \mathrm{~mm}$ nitrate stock appears to have been destroyed.

It was on the basis of this I6 mm safety copy that in the late I96os, Bill Holm, an art historian from the Burke Museum in Seattle with a specialist interest in the North Pacific Coast peoples and George Quimby, then a curator in the Department of Anthropology at The Field Museum, began to collaborate on a first reconstruction of the film. This was a very challenging task given the fragmentary state of the material. However, they did have the advantage that at that time quite a number of Kwakwaka ${ }^{\prime} w a k w$ who had been directly involved in the production were still alive, so it was possible to interview them and get their responses to the material that remained. In the summer of I968, Holm travelled around various Kwakwaka 'wakw villages screening a loosely edited version of the film and was impressed by the way in which audiences often responded to the images with improvised dialogue and song. This encouraged him to think that he should create a new soundtrack for the film, and in 1972, with the assistance of a group of student film-makers from Rice University in Houston, Texas, he arranged for these oral reactions to be recorded in an auditorium in Victoria, in the south of Vancouver Island. ${ }^{28}$ 
The Holm and Quimby reconstruction was eventually released in I973 and ran to 44 minutes, around half the original length of the film. The general effect of this reconstruction was to reduce the film's melodramatic character and enhance its informationally ethnographic qualities. Believing that it oversensationalised the role of head-hunting in Kwakwaka life, Holm and Quimby changed the title of the film to In the Land of the War Canoes. The original melodramatic intertitles were greatly reduced in number and their extravagant language replaced with more sober informational phrases. The font employed was highly functional and there was no decorative border as there had been in the original film. The chanting and improvised dialogues that the Kwakwaka'wakw had produced in response to a preliminary assembly of the film were superimposed on certain passages, although these were not subtitled, so they served, in effect, merely to give a general ethnographic 'feel' to the film rather than to provide dialogue as such. A series of ambiental sound effects were also added to further naturalise the general aesthetic effect of the film - breaking waves, the sound of canoes surging through the water, seagulls screeching.

Holm and Quimby also introduced certain changes to the image track. A scene that was vividly remembered by many participants but which had been entirely lost was refilmed: this involved the throwing of a life-size dummy from a cliff top to simulate the killing of an innocent traveller by Yaklus's war party. On the other hand, they chose to eliminate the mugshot of Motana inside the whale carcass, since they considered this to have no place in the story. Another innovation was the introduction of an opening pre-title 'hook' in the form of the dramatic shot of the approaching canoes with the masked figures dancing in the prows (see figure 2.5).

While this first reconstruction undoubtedly saved the film from total oblivion and was also much appreciated by Kwakwaka ${ }^{\prime}$ wakw audiences, it was subsequently criticised for presenting the film as if it were some flawed attempt to make an academic ethnographic documentary rather than what Curtis had originally intended it to be, namely, a fictional 'motion picture drama' aimed at popular audiences. A second reconstruction, which aimed to be closer to the original aesthetic of the film was subsequently released, under the original title, in 2008. This was initiated and coordinated by Brad Evans, an English literature scholar who first became interested in the film on account of the language of the intertitles, and Aaron Glass, an anthropologist and film-maker who has carried out research with present-day Kwakwaka 'wakw over many years. This second reconstruction project was kick-started by the chance discovery by Glass, in an archive of Curtis's papers in the Getty Research Institute in Los Angeles, of the original musical score. This had been commissioned by Curtis from John J. Braham, an English musician best known for his work with the US branch of the Gilbert and Sullivan light opera company, and who, the previous year, had 
composed the score for Frank E. Moore's version of Hiawatha, the AMNHsponsored production.

In carrying out their reconstruction, Evans and Glass had the great advantage that following an approach by Glass, the best part of two further reels of the original film were discovered in the vaults of the UCLA Film and Television Archive. Although they were also extensively damaged, in conjunction with further text-based materials discovered in the Getty Research Institute as well as with several dozen frames clipped from a $35 \mathrm{~mm}$ print that had been submitted to the Library of Congress as a means of ensuring the copyright of the original film, Evans and Glass were able to use these additional rolls to establish a clearer idea of the overall structure of the film than had been available to Holm and Quimby.

This newly discovered material allowed Evans and Glass to add a number of scenes to the film with the result that their reconstruction runs to 66 minutes (i.e. half as long again as the Holm and Quimby reconstruction), though still only about three-quarters of the probable length of the original film. As well as restoring the original main title, Evans and Glass restored the melodramatic intertitles with their period font and decorative borders. The war canoes 'hook' and the additional scene filmed for the Holm and Quimby reconstruction were eliminated, and the Motana mugshot was reinserted. Also eliminated were the Kwakwaka ${ }^{\prime}$ wakw chanting and improvised dialogues, as well as the ambiental sound effects added by Holm and Quimby. These were all replaced by a newly recorded performance of the original Braham score. (This was supposedly based on some phonograph field

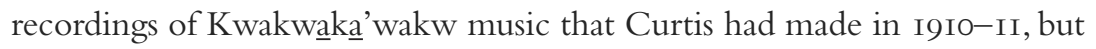
in fact, it seems to owe very little, if anything, to these.) As a final touch, various scenes in the film were colour-tinted as it was supposed that they would have been in original film. It is on this version of the film that the analysis offered here has been based.

However, if it is inappropriate to construe Head Hunters as an imperfectly realised ethnographic 'documentary' in the modern sense, it would be equally mistaken, Evans and Glass argue, to consider it merely as a romantic outsider's construction imposed on entirely passive indigenous subjects. Instead, they suggest, it should be understood as a collaborative venture between Curtis and the Kwakwaka 'wakw. They point out that by the time Curtis arrived to make his film, the Kwakwaka 'wakw had long been involved in performing a heritagised version of their culture for external audiences. As early as I893, through coordination between Franz Boas and George Hunt, some fifteen Kwakwaka ${ }^{\prime}$ 'wakw had performed their dances at the Chicago World's Fair. Later, in 1904, two other Kwakwaka ${ }^{\prime}$ wakw dancers had performed at the Louisiana Purchase Exposition in St Louis, as well as in The Field Museum on their way home. On a more regular basis, the Kwakwaka ${ }^{\prime} w a k w$ were accustomed to performing their culture for visiting dignitaries of various 
kinds, as well as for tourists who arrived on the cruise ships stopping off on their way to Alaska. Evans and Glass suggest that rather than condemn Curtis for misrepresenting the reality of Kwakwaka 'wakw life, be it in I9I4 or at some indeterminate pre-contact period, one should ask to what extent this film is the result of decisions by the Kwakwaka'wakw themselves as to how they wished to be represented at that particular historical juncture. ${ }^{29}$

More generally, Evans and Glass propose that instead of thinking of Head Hunters as a representation of the Kwakwaka'wakw that is either true or false, it would more be profitable to think of it as a representation in dialogue with the Kwakwaka 'wakw and their evolving relationship with their own tradition. This is certainly the framework through which Evans and Glass approached their reconstruction of the film. Throughout the process, they collaborated closely with the U'mista Cultural Society, a Kwakwaka $\underline{\text { 'wakw }}$ organisation dedicated to the preservation of their cultural heritage, based at Alert Bay, which lies further down the eastern coast of Vancouver Island from Tsaxis, on Cormorant Island. They had a particularly close association with the executive director of this organisation, Andrea Sanborn, and on the website that first reported on their reconstruction work, she was listed as a co-author of the project. Sadly, however, she passed away before the project was completed.

The collaboration has nevertheless continued in various forms, notably through the involvement of a semi-professional Kwakwaka $\underline{a}$ 'wakw dance troupe, the Gwa'wina (Raven) Dancers. When the new version of the film was taken on a tour of six US and Canadian cities in 2008, the Gwa'wina Dancers would often perform after a screening, including some of the dances seen in the film in their repertoire, answering audience questions not only about the film but also about how they related to the world that it represents. ${ }^{30}$

\section{The Creative treatment OF ACTUAlity: NANOOK OF THE NORTH}

Important though Grass and Head Hunters may be in the history of ethnographic cinema, by far the most influential work to emerge from the early twentieth-century cinematic crucible of travelogue and melodrama was the work that has been identified by many as the original film of the ethnographic genre - Nanook of the North. Released in I922, almost a decade after Head Hunters and two years prior to Grass, this film portrays the day-to-day life of an Itivimuit Inuit man living with his family on the eastern shore of Hudson Bay, in the northernmost reaches of the Canadian Province of Quebec. The director, Robert Flaherty, was neither an academic researcher, nor a professional film-maker, but rather a US mineral prospector who had 
been working in the Canadian North for about ten years by the time he came to make this film. ${ }^{31}$

Although actually shot over the course of more than a year, the main body of the film consists of a chronicle of the subjects' lives over what are ostensibly two days, following them in a range of subsistence practices, mostly hunting and fishing, as well as in some domestic routines, as they seek to wrest a living from the challenging Arctic environment. In doing so, Nanook offered a degree of intimacy with the subjects coupled with a technical mastery of the medium that had not been previously achieved in any form of non-fiction film-making.

By a thought-provoking coincidence, Nanook was released in the same year that Bronislaw Malinowski published The Argonauts of the Western Pacific. Although Flaherty was precisely the kind of explorer figure despised by 'the Ethnographer', as Malinowski styled himself, there was a certain similarity in their methods: Nanook and Argonauts were both works arising from extended first-hand immersion in the world of the subjects; though both covered certain public moments in their subjects' lives, they also described and celebrated the detail of their more intimate personal experiences. But most significantly of all, the ultimate goal of both author and film-maker was to be able to evoke their subjects' vision of their world, or as Malinowski put it, albeit in the androcentric colonial language of the time, 'to grasp the native's point of view, his relation to life, to realise his vision of his world' and, above all, 'the hold that life has on him'. ${ }^{32}$

Notwithstanding the frequent references to Flaherty's status as the 'father' of ethnographic documentary, and the various parallels that one might draw between his methods and those of Malinowski, Nanook presents such a romanticised vision of Inuit life and involves such a degree of construction and artifice that, if judged by present-day criteria, it is highly doubtful that it would be classed as a 'documentary' at all, ethnographic or otherwise, at least not in the conventional modern sense of the term. However, it is important to understand that Flaherty was not trying to make a documentary in the modern sense. Indeed, to attempt to read Nanook as some sort of early and imperfect stab at making an ethnographic documentary in the modern sense leads one into the same sort of interpretative errors that Holm and Quimby made in their very well-intentioned but ultimately misconceived reconstruction of Head Hunters. Instead, I would suggest that one should think of Nanook as something rather different, namely, as an innovative attempt, drawing on the tropes of the travelogue and the melodrama, to tell an intimate personal story about everyday life in a culturally exotic setting (figure 2.6).

In considering Nanook, one should bear in mind first and foremost that it was made for a popular cinema audience. In the I920s, there were no art cinemas, nor international ethnographic film festivals. The principal 

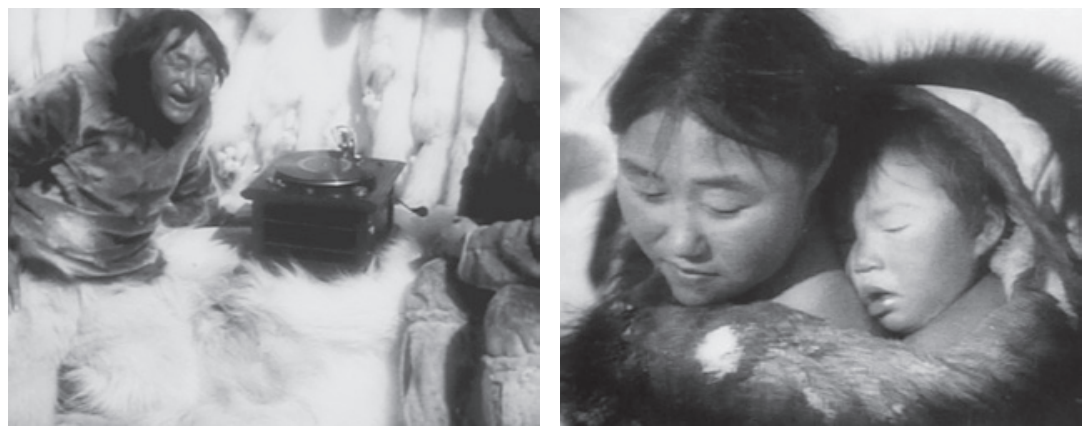

2.6 Nanook of the North (I922) retained certain features of the travelogue, but offered an unprecedented intimacy with the subjects. Left, Nanook is amused by a gramophone at the trade store; right, Nyla, Nanook's screen wife and Flaherty's real life lover, builds an igloo.

patrons for films of this kind were the commercial cinema chains and their greatest concern was not with ethnographic accuracy but rather with whether their audiences would be entertained. ${ }^{33}$ Second, we need to remember that even if Flaherty had been seeking to make an ethnographic documentary in the modern sense, involving minimal interference in the lives of the subjects, there would have been severe technical obstacles to his doing so, particularly in demanding sub-Arctic conditions. Much of what today's documentary film-makers would be able to film without intervening in any way was then only possible through considerable contrivance.

A great deal has been made of the technical contrivances that Flaherty adopted in order to make Nanook, as if these somehow undermined his 'documentary' purpose. One that has attracted particular comment is the igloo that Flaherty had specially built for filming: in order to give himself sufficient room and light to film, Flaherty asked the Inuit to build an igloo that was very much larger than normal and with one side missing. The sequences of the family getting up two-thirds of the way through the film and going to bed at the end of the film were then specifically enacted for the camera at Flaherty's request in this one-sided igloo. However, as contrivances go, this is surely not that significant, certainly for the period: it would be many years before documentary film-makers would be able to light the interior of an igloo. Much less commented upon, but in my view much more noteworthy for reasons considered below, is that these two sequences of getting up and going to bed were clearly filmed at the same time but were then used at separate points in the film and in the reverse order.

Other contrivances involved in the making of Nanook were not motivated in any way by technical constraints but were simply a consequence of the fact that Flaherty was not aiming to produce a literal account of the world, 
but rather a dramatisation of it, one that involved, in John Grierson's famous phrase, 'the creative treatment of actuality'. Although they were all local people, the principal subjects were, in effect, actors acting out their own lives, though always under Flaherty's direction. There was no script as such, but every scene was carefully prepared in advance in consultation with the subjects. Flaherty even gave this subjects screen names. The real name of the principal subject was Alakariallak: his screen name was a transliteration of nanaq, meaning 'bear' in Inuktitut, the Inuit language. Flaherty gave him this name (which may also have been his local nickname) not only because he realised that 'Alakariallak' would be too long for cinema audiences to get their tongues around, but also because he originally intended that the film should culminate in a scene in which Alakariallak killed a bear. For the same reason, he asked Alakariallak to wear bearskin leggings, despite the fact, at least according to some specialist commentators on the film, these were not traditionally worn in his part of Inuit territory. But although Flaherty and Alakariallak spent several weeks on an expedition to film the hunting of a bear, they came back empty-handed and, according to Flaherty's extended account of the journey, almost died of starvation on the way back home.

Nor was it only screen names that Flaherty devised for his protagonists: he also devised the relationships that they should represent in the film. For, in reality, 'Nyla - the Smiling One', Nanook's screen wife - was not actually Alakariallak's wife, but rather his daughter-in-law, one Maggie Nujarluktuk. She was also Flaherty's lover, and after his departure she bore him a son, Joseph, who took his father's surname, though Flaherty never recognised him and may not even have known about him. There is also a second young woman, Cunayou, who appears in various domestic scenes, including in the igloo-building scene in which she is carrying a baby. She is also shown sleeping with the baby in the getting up and going to bed scenes. How she fits into Nanook's on-screen family is not exactly explained in the film itself. In an early scene, when she emerges from Nanook's kayak with the rest of his on-screen family, she looks like a young adolescent, possibly Nanook's daughter. But in the later scenes, she looks much older, leading the viewer to wonder if it is the same actress in both cases. Is she supposed to be a second wife, to whom Flaherty eventually decided not to draw attention in consideration of the possible prejudices of the audience? It has been claimed that she too was Flaherty's lover. But this may be just another wrinkle in the aura of myth and legend that surrounds the person of Flaherty. ${ }^{34}$

All these fictional features clearly limit the status of Nanook both as documentary and as ethnography, at least as these terms are most commonly understood today. However, it is what Flaherty left out of the film rather than what he put in that most casts doubt on its status as an ethnographic 
documentary in present-day terms. Even Flaherty's contemporaries had doubts about the fact that apart from an anodyne scene at the trading post of Revillon Frères, the French furriers who sponsored the film, the contact of the Inuit with the outside world was rigorously excluded. Not only are there no rifles, no steel hunting traps, nor other technological evidence of contact, but the social effects of contact are omitted too. But Flaherty was very clear in his own mind that he did not want to show what he considered to be the disastrous effects on Inuit life of missionaries, mining camps, schools, alcoholism and prostitution. Rather, he wanted to show the Inuit's 'former majesty and character ... while it is still possible - before the White man has destroyed not only their character, but the people as well'.35

Yet even when considered as a historical reconstruction of the pre-contact period, Nanook is of limited ethnographic value, at least if one accepts the view of Flaherty's contemporary, the distinguished cultural anthropologist Franz Boas. Although Boas is perhaps best known for his later work among the Kwakwaka'wakw, he carried out his doctoral fieldwork on Baffin Island, to the north of Hudson Bay where Flaherty worked, among an Inuit group of similar cultural characteristics. Boas was also interested in the potential of film-making for academic anthropology. But, in a letter written to a leading cinema industry figure some ten years after the release of Nanook, Boas commented that if only 'a man who knows Eskimo life in and out had been at hand to direct a film like Nanook, many exceedingly picturesque and interesting features of native life might have been brought in which would not only have improved the quality of the film but would have also made it more attractive to the general audiences' ${ }^{36}$

In considering this opinion, one should allow for the fact that anthropologists without extensive first-hand film-making experience, now just as much as then, are almost invariably disappointed by the limited amount of information that it is possible to include in a film. Even so, Boas's sense that Nanook displayed a lack of familiarity with Inuit life should stand as a corrective to the sometimes too-ready assumption, particularly in the screen studies literature, that Flaherty's relationships with the Inuit as his field assistants on his mineral prospecting trips and later as his film protagonists - not to mention as his lovers - would translate automatically into a genuinely well-founded ethnographic knowledge of their social life and culture.

What is certainly the case is that considered as an ethnographic account of Inuit society, be it in 1920 or at some indeterminate period before the arrival of Europeans, Nanook makes almost no reference to social life beyond the nuclear family, nor to economic life beyond subsistence tasks, and there is no allusion to shamanism nor to any other aspect of Inuit religious life, which subsequent ethnographic study has shown to be of great importance to the Inuit. But given that Flaherty's decidedly underwhelming autobiographical account of his decade or more living among his 'Eskimo friends' 
consists of little more than a series of prolonged anecdotes about the logistical difficulties of travelling and making films in the sub-Arctic, it seems that these social and cultural aspects of Inuit life were not matters to which he paid too much attention anyway. ${ }^{37}$

\section{The innovations of NANOOK OF THE NORTH: THE NARRATIVISATION OF EVERYDAY LIFE}

Yet however limited the ethnographicness of Nanook may be in regards to the actual content of the film, in two other respects, which are more methodological, it represents an important precursor for future developments in the authorship of ethnographic films. One of these concerns the way in which it presents Inuit daily life through a narrative structure based upon what might be termed an 'as if chronology', that is, a chronology that has been entirely created in the edit suite but which is modelled on a natural chronology. Whereas the device of the unitary journey could be used in the travelogue format to impose order and direction on diverse footage gathered opportunistically in the course of an expedition, an 'as if chronology' - variously construed as a day, a season or a year, or some other easily recognisable unit of time - can be used to impose order and direction on material shot in a given place or among a given group of people, usually over much longer periods than is suggested by the fictitious chronology itself. As one of the most innovative features of Nanook from an authorial point of view, this aspect of the film deserves our closer attention. ${ }^{38}$

In a manner that is suggestively similar to the later case of Grass, the first third of the film, that is, the first 25 minutes, acts as a sort of prelude to the main body of the film and has a number of features typical of the travelogue format. It begins with a classic travelogue arrival trope: a pointof-view shot taken from on board a large vessel as it pushes its way through a sea littered with ice floes. This is followed by a series of maps interspersed with rolling explanatory title cards stressing the isolation and precariousness of life in the region: in a sense, the Inuit are, like the Bakhtiari, also a 'Forgotten People'. We are then presented with two striking close-up portraits of 'Nanook, The Bear' and his wife, 'Nyla - The Smiling One'. Next come some rather disconnected vignettes of Inuit technical processes (making a moss fire, building a kayak etc.) before Nanook and his family arrive at the Revillon trading post. Here there are a number of jokey scenes, including one of Nanook listening to a phonograph and testing out a vinyl record with his teeth, which are straight out of the same drawer as similar scenes of 'natives' marvelling at modern technology that frequently crop up in the Martin and Osa Johnson travelogues. The prelude then culminates with two sequences in which Nanook demonstrates his prowess as a hunter, first 
in fishing for sea trout amid the ice floes, and then the celebrated scene in which he harpoons a walrus and, with the help of three other men, hauls it out of the sea.

Also as in Grass, there is then a sudden change of gear, narratologically speaking, as an intertitle announces the arrival of 'Winter ...'. But whereas in Grass, the progress of the Bakhtiari journey takes over at this point as the structuring principle of the film, in Nanook it is an 'as if' chronology. In effect, the remainder of the film is presented as two days in the life of Nanook and his family. The first day mainly consists of them slowly making their way over the chaotic ridges of snow caused by the ice floes driven inshore by winter gales. After Nanook digs out a white fox caught in one of his traps, there is a lengthy sequence in which, while their children play, he and Nyla build an igloo for the night, assisted by the mysterious 'second woman', Cunayou. Once the igloo is built, there are some charming sequences of Nanook playing with his children before the whole family withdraws into the igloo, and with a single shot of a hearthstone arrayed with seal-oil candles, the first day ends.

The second day begins with a lengthy getting up sequence, as the entire family is shown emerging from beneath its bedding of furs. This is clearly based on the second half of the footage shot in the artificial igloo described earlier. The family's naked torsos are briefly exposed, reminding us simultaneously of the warmth and of the vulnerability of the human body in such an environment. Nyla chews Nanook's frozen boots to soften them, and plays with her baby, rubbing noses in the 'Eskimo kiss', another chapeau to the travelogue format.

The main scene of this second day is the longest in the film and shows the harpooning of a seal through its blowhole in the ice. However, using the technique of delayed disclosure that he would employ throughout his film-making career, Flaherty does not at first let the audience know that it is a seal that will emerge from this small hole. Nanook plunges his harpoon through the hole, and as he struggles to pull out whatever it is that lies below, the jocose travelogue style returns once more. He is dragged back and forth, turning somersaults and sliding on his backside in a Chaplinesque manner. In fact, this bit of comedic 'business' was entirely contrived: the other end of the harpoon rope was being pulled, not by a seal, but by an off-screen group of fellow Inuit. ${ }^{39}$

Eventually, with the assistance of the whole family, Nanook manages to land his prey and it turns out to be a very dead-looking seal. Its meat is then shared out around the ravenous dogs. But by now it is getting late, the fighting between the dogs is delaying matters and the wind is starting to get up, so the family takes refuge in an igloo that is supposedly 'abandoned', but which bears an uncanny resemblance to the igloo seen being built earlier in the film. The second day, and the film as a whole, then ends with 
a sequence of the family bedding down for the night, using the first half of the footage shot in the artificial igloo. In a particularly memorable editorial device, these shots of the family are repeatedly intercut with shots of the dogs outside becoming increasingly covered in snow. The final shot of the film is a close-up of Nanook apparently asleep, gently breathing.

The material for these two days in the life of Alakariallak and his fictional family, we should remember, was, in reality, shot over the course of a year. In terms of its general ontological status therefore, one could argue that the narrative structure underlying Nanook is just as fictional as the narrative structure underlying Head Hunters. But there is an important difference: whereas Head Hunters was based on a series of entirely imaginary, extraordinary events, the structure of Nanook is made of up a series of everyday events that may not have happened exactly as shown in the film, nor exactly in that order, but which could have happened in something approximating this manner. If one puts aside certain matters of content, such as the many ethnographic inaccuracies and comedic effects introduced to spice up the story for the popular audience, this form of filmic narrative is not dissimilar in formal terms to the narrative accounts one often encounters in ethnographic texts from Argonauts of the Western Pacific onwards, in which a typical routine is described as happening over a given length time, be it over a single day or a longer period.

In effect, what Flaherty discovered in making Nanook was that the everyday could be dramatised. 'What biography of any man', he asked rhetorically, 'could be more interesting?' 40 Rather than being built on a series of fanciful dramatic events, as Head Hunters had been, Flaherty's narrative strategy consisted simply of following an imaginary but naturalistic 'as if chronology'. This not only provides a cumulative link between otherwise disconnected scenes of everyday life, but also ensures an appropriate sense of closure at the end of the film. The audiences of Nanook knew that the film had come to an end and that they could go home satisfied, not because the hero had won the maiden's hand and the Evil Sorcerer and his brother had met a terrible fate, but rather because the hero had settled down to sleep, snug within his igloo, while outside in the gathering gloom his dogs endured the Arctic blasts.

\section{The INNOVATIONS OF NANOOK OF THE NORTH: PARTICIPATION AND FEEDBACK}

The other feature of Nanook that has been much admired by ethnographic film-makers of later generations are its participatory methods, that is, the way in which Flaherty actively involved his protagonists in the making of the film. This in itself was not entirely original: as shown in Chapter I, in 
the very first example of ethnographic film-making in the field, Alfred Haddon had sought the collaboration of his subjects in filming the MaloBomai dances, and it was they who made the cardboard masks used in the film. Similarly, as discussed, the Kwakwaka'wakw appear to have actively participated in the creation of In the Land of the Head Hunters. What was distinctive about Flaherty's approach was that this process of consultation also involved what would later become known as 'feedback screenings'.

For, defying the lack of mains electricity in his cabin on the edge of Hudson Bay, Flaherty developed his rushes on the spot and then screened them to his subjects at regular intervals as the filming proceeded. Not only did these screenings allow the subjects to understand the nature of filmmaking - when Flaherty first arrived, he discovered that many Inuit could not even 'read' a still photograph - but they also inspired the Inuit to work with him as partners. When the Inuit saw the rushes of the first day's shooting (the walrus hunt, as it happened), they were entranced. Thereafter, he reported, they were constantly thinking up new scenes for the film.

It was these collaborative methods that undoubtedly accounted for the unprecedented sense of intimacy between subjects and film-maker that is so striking about Nanook. When asked how he had managed to achieve this, Flaherty put it down to the simple fact that the Inuit had allowed him to share their way of life. Far from looking down on his subjects, as the travelogue film-makers of his era invariably did, Flaherty looked up to them. As he would later put it:

I had been dependent on these people, alone with them for months at a time, travelling with them and living with them ... My work had been built up along with them; I couldn't have done anything without them. In the end, it is all a question of human relationships. ${ }^{41}$

We should not, however, allow ourselves to be entirely beguiled by the Flaherty legend. Although his methods were unprecedentedly participatory, he remained in firm control. Whatever the Inuit subjects may have wished to do, the 'aggie', as Alakariallak referred to the film-making process, 'would always come first'. ${ }^{42}$ There were also some aspects of Flaherty's relationship with his subjects that many audiences today find difficult to approve. The references in the initial rolling intertitles to 'the happy-golucky Eskimo' and the 'simple Eskimo', intended by Flaherty to be positive descriptions, would be considered by most modern audiences, including the Inuit themselves, to be intolerably patronising. There were also clearly some aspects of his relationships with Inuit women that would be severely questioned today.

But we should be wary of being too presentist in our judgements. For the era in which he was working, Flaherty's views were certainly progressive and this was reflected in the intimate and assured way in which he presented 

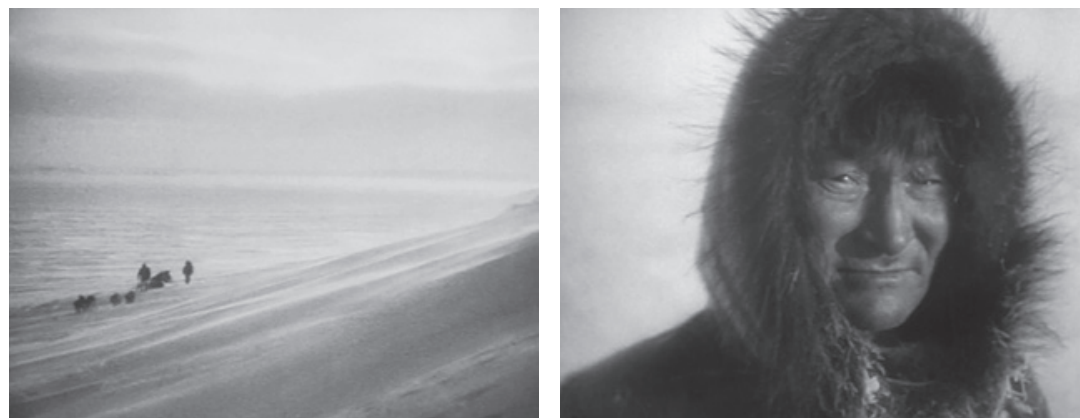

2.7 Nanook of the North (I922). Left, the family makes haste to find shelter before the night closes in; right, Alakariallak and 'the hold that life has'.

his Inuit subjects. Previously the protagonists of films about 'other cultures' had been no more than distant figures, without character or individuality. Nanook is a much more rounded character than any we find, not merely in any previous works, but even in the ethnographic films of Margaret Mead and Gregory Bateson that were shot more than a decade later.

There is surely no more telling instance of this than the moment when Alakariallak, framed in close-up, looks directly down the camera lens as he is first introduced to us as 'Nanook, The Bear'. Maggie Nujarluktuk gets the same treatment as 'Nyla - The Shining One', immediately afterwards, but she is shot in semi-profile, swaying slightly, lips moving in some apparently amused comment, and in soft focus like some Hollywood diva. It is an entirely formulaic framing that gives no sense of her individual being. In contrast, Alakariallak's look is directly at the camera and is far more striking. He averts his eyes momentarily but then looks again with an air of curiosity, but also of confidence, no doubt arising from the secure relationship between himself and the film-maker. Rendered all the more poignant by the knowledge that within two years he had died of starvation on a hunting trip, that single image offers us an almost unbearable sense of the being of Alakariallak, the man in flesh and blood, and - in the words of the Ethnographer - 'the hold that life has on him' (figure 2.7).

\section{The Legacy of Nanook of the North}

In the years following Nanook of the North, Flaherty went on to make a number of other fictional films set in culturally exotic locations. These included Moana (I926), a saccharine story about a young man's coming of age in Samoa; Man of Aran (I934), about a family's struggles to make a living on an island off the west coast of Ireland; Elephant Boy (I937), a rags-to-riches 
tale about the ambition of a young Indian elephant driver to become a great hunter, and Flaherty's last film, Louisiana Story (I948), another coming of age story, this time rather wistful, which centres on a young boy witnessing the arrival of the oil industry in the waterlogged bayous that are his home.

Although Flaherty generally employed much the same participatory methods in making these films, they were not based on the same degree of long-term engagement with the subjects as Nanook. Nor did they reveal any greater interest in social and economic relationships beyond the nuclear family and subsistence activities. If anything, they were generally even more fictionalised than Nanook and although it could be argued that some of these later films possessed certain ethnographic qualities, they too could only be considered documentaries by present-day norms with some degree of qualification.

Nor does Flaherty's work appear to have had any influence whatsoever on the film-making of the academic anthropologists of his own time. The great Soviet film-makers of the I920s were much impressed by Nanook: Sergei Eisenstein claimed that they showed their print of the film so many times that they completely wore it out. John Grierson and his acolytes in the British Documentary Movement were similarly inspired and invited Flaherty to the UK to work with them. Yet the impact on Flaherty's anthropologist contemporaries was negligible. Not only Franz Boas, but also his student Margaret Mead, were certainly aware of Flaherty's films and, as late as I972, Mead even based a diorama of Samoan life that she completed for the AMNH on a scene from Moana. But Flaherty's work did not influence Boas and Mead's actual film-making practices, nor did it influence their way of thinking about the role of film in anthropology. On the contrary, Mead regarded Flaherty's 'artistic' approach to film-making as the complete antithesis of the way in which anthropologists should be using film in their work. ${ }^{43}$

Indeed, it was only after the Second World War that ethnographic filmmakers would come to find inspiration in Flaherty's work. Perhaps his greatest admirer was Jean Rouch, who liked to claim Flaherty as his 'totemic ancestor'. What Rouch particularly admired about Nanook was the degree of intimacy that Flaherty had managed to achieve with his subjects. Moreover, Rouch realised that this was a direct result of Flaherty's collaborative methods, particularly his use of feedback screenings, and he made these methods the cornerstone of his own praxis, an approach that he would dub 'shared anthropology' ${ }^{44}$

But Rouch followed Flaherty in another way also, that is, in his willingness to work with his subjects to produce fictionalised accounts of their own everyday lives. Rouch produced a dozen feature-length films based on this methodology that third parties have dubbed 'ethnofiction'. In that it involved a prolonged collaboration with Alakariallak and his screen family to produce 
a dramatised version of their everyday life, I suggest that in making Nanook of the North, Robert Flaherty was the author, not of the first 'ethnographic documentary' as we would understand those terms today, but rather of the first 'ethnofiction'.

\section{Notes}

1 These films can be viewed on the Library of Congress website at www.loc.gov/ item/o0694II4 (Buffalo Dance) and www.loc.gov/item/oo694I39/ (Sioux Ghost Dance). The latter film is sometimes incorrectly identified as 'Indian War Council'.

2 The Lumière view that is widely shown as supposedly the 'first film' is in fact probably only a re-make, being only one of as many as five different versions of the same view that were shot between March I895 and February I897. The very first view appears to have been lost or destroyed. The most authoritative catalogue of Lumière films is the one edited by Michelle Aubert and Jean-Claude Seguin (I996). See pp. I9, 2I4-I5 of this work for a discussion of the difficulties in identifying the very first view.

3 See Chapter I, p. 6o.Veyre's footage also just predates that of Alfred Haddon, which was shot in Melanesia on 5 and 6 September I898 (also see Chapter I, pp. 3I-2).

4 Pierre Leprohon (1903-93) was a journalist and writer on cinema who is remembered in France for his book L'Exotisme et le Cinéma, published in 1945. This work is disfigured by some egregiously racist observations as well as by certain major ethnographic errors. However, it contains a number of interesting ideas and offers a very useful review of early twentieth-century examples of what he terms cinéma exotique, that is, both fictional and non-fictional films about 'other cultures'. Leprohon himself proposes that the term reportage should be reserved for films by named directors who had some particular message to impart while the work of the early newsreel operators should be referred to simply as 'travel documentaries' or 'open air films' (scènes de plein air) as they were known at the time because they were not made in studios (see Leprohon (I945), I63). In contradicting Leprohon and employing 'reportage' to refer to the work of the latter, I would argue that my usage reflects the less elevated connotations of this term in English. On the specific matter of the rates paid to early newsreel operators, see Leprohon (I945), I9-2I.

5 Many early Gaumont and Pathé films are available at their joint archive at www.gaumontpathearchives.com/index.php?html=I7.

6 I am greatly indebted to Faisal Devji, reader in Indian History at the University of Oxford for these comments on the historical significance of the film.

7 See Bell, Brown and Gordon (2013), 247. Copies of the films arising from both the AMNH and the Harvard collaborations with Pathe are held at the National Anthropological Film Center (until recenty the Human Studies Film Archives) at the Smithsonian Institution.

8 A selection of Baby-Pathé films is available on the Princeton University website at rbsc.princeton.edu/pathebaby/. However, they are also available in rather better quality and with an explanatory introduction on a private website hosted on YouTube: www.youtube.com/user/StephendelRoser.

9 See Ruoff (2002), Altman (2006), Gordon, Brown and Bell (2013) among many possibilities in an extensive literature on the travelogue.

10 See Homiak (2013), vii-xi. A variant of the travelogue format - albeit, one that is now generally reverential towards its subjects' way of life - is with us still in the form of the television travel show featuring celebrity presenters sharing their experience of 'first contact' with cultural Others across the globe.

11 See www.youtube.com/watch? $=60004 F Z 2$ bes. The clip comes from Congorilla, commonly said to be the first sound film shot entirely in Africa. Specifically on the Johnsons, see Russell (1999), I40-8; Lindstrom (2013). 
12 This account of the making of Grass draws upon the excellent study by Hamid Naficy (2006). For an interesting discussion of the narrativity of this film, see Crawford (1992). For general historical and ethnographic background, see also Bradburd (20I3).

13 David MacDougall reports that at a screening of the film that he attended as a student in Los Angeles in 1968, Merian Cooper explained that the footage of the Bakhtiari migration was initially intended merely to serve as background material for a feature film that was never made (MacDougall 20I9, I62, I88, n.6). If so, this might explain why Harrison has such a slight presence in this part of the film.

14 These figures are those of the film-makers, who claim in the intertitles that the migration involved 'fifty thousand feet' and 'half a million hooves'. Although these numbers are very likely to have been exaggerated, it was still clearly a vast migration of people and animals.

15 Naficy reproduces an interesting comment by one of the writers of the intertitles, a certain Terry Ramsey (actually spelt 'Ramsaye' in the opening credits of the film), who claims that it is these intertitles that impart an epic character to an event that the Bakhtiari themselves consider to be no more than a twice-yearly 'chore' (Naficy 2006), I38, n. 5 .

16 The image of Haidar Khan, presented in the film as the noble leader of his people, is considerably at odds with the film-makers' characterisation of him in print, which Naficy paraphrases as 'gorilla-like, brutal, a wife-beater, an opium smoker, and a horse thief, who loafed about while his people did the work' (2006), I29-30.

17 Griffiths (2002), 236-7, 276-8. Colin Browne reports that a pre-existing Hiawatha pageant first filmed in Ontario in I9O3 involving an Ojibwe cast, was then filmed on two further occasions with a Mohawk cast, in 1908 in Quebec and again, in Montreal, in I9II. Remarkably, this last version is reported to have been in colour (Browne 20I4), I75-6.

18 Jordan (1992), I54-7, I76-9, Evans (2014), 205-6. All these early Griffith films are available on YouTube.

19 See O’Reilly (1970), 289-90; Piault (2000), 26-7.

20 My discussion of this film draws on a number of sources, including Curtis (I9I5), Holm and Quimby (1980), Rony (I996), 90-8, Evans (I998), but above all, on the many contributions to the excellent volume edited by Brad Evans and Aaron Glass (20I4), particularly their own Introduction (pp. 3-26). I am also indebted to Aaron Glass for his very valuable personal comments during a meeting in May 2015 and in response to the manuscript of this chapter in December 2018.

21 See Chapter I, p. 76 note 58.

22 Gidley (I982), 7I-2; Gidley (20I4), 53.

23 This is reproduced on p. 52 of Evans and Glass (20I4), in figure I.5.

24 My sceptical view regarding Curtis's skills as a film-maker, while unusual, is not unique: Jere Guldin, of the UCLA Film \& Television Archive, who restored the latest version of the film and therefore knows it particularly well, has commented that Curtis 'an immaculate still photographer, was not much of a hand with a motionpicture camera' (Guldin 20I4, 26I).

25 See particularly Glass and Evans (2OI4), 22-3; Evans (20I4), 206-8.

26 Aaron Glass (personal communication, December 20I8) has suggested that this may be a self-conscious reference to the well-known biblical story of Jonah that was inserted to round off the whale hunting sequence. There is also an intriguing similarity between this shot and the famous shot of Nanook emerging from his igloo to acknowledge the camera in Nanook of the North (see Browne 20I4, I7I). Whatever the precise reason for it, this shot can be understood as a 'cinema of attractions' moment that interrupts the general flow of the narrative diegesis.

27 Glass and Evans (20I4), 26.

28 See Holm (2014).

29 See particularly Glass and Evans (20I4), IO-II, I6-I9.

30 See Glass (20I4). 
31 The person and life of Flaherty is hedged around by legend and mystery. He himself liked to put about the apocryphal story that he had learned film-making from a missionary who later hung himself in his darkroom, though the more prosaic reality is that the little training that he did receive actually consisted of a three-week course at the Kodak factory in Rochester, New York. Unless otherwise stated, this and other background details regarding the making of Nanook are drawn from Rotha with Wright (I980), Barnouw (I983), 23-45 or Ruby (2000), 67-93.

32 Malinowski (I932a), 25.

33 See the remarkably tacky promotional materials for Nanook prepared for cinema managers and reproduced in the journal Studies in Visual Communication 6 (2) (1980). The subtitle and promotional strap-line for the film was 'A Story of Life and Love in the Actual Arctic'.

34 See Rony (I996), I23; Marcus (2006), 205, 2I4-I8; Winston (20I3a), II.

35 Cited in Rotha with Wright (1980), 47.

36 Cited in Jacknis (1987), 63.

37 See Flaherty with Flaherty (1924).

38 The argument concerning the narrative structure of Nanook in the following paragraphs has been strongly influenced by the ideas of Brian Winston (see particularly Winston I995, 99-IO2; also Winston 20I3). The film exists in a number of different versions, but the version referred to here is the one featured on the Criterion Collection DVD released in I998. This version was prepared in collaboration with the Film Preservation Society and is based on a re-mastering of Flaherty's personal print acquired by the BFI in I939.

39 This scene has been the subject of much discussion in the screen studies literature, though this has often been poorly informed. It seems to have been the celebrated French film theorist André Bazin who started this discussion when he described this scene as 'one of the loveliest in all cinema' on the grounds that it shows 'the actual waiting period' and includes 'hunter, hole and seal all in the same shot', without any recourse to montage. As such, he claims, it shows 'respect for the spatial unity of an event when to split it up would change it from something real to something imaginary' (Bazin 2005), 27, 50-I. In fact, however, over the 20-second waiting period in the film (very much less than the 20-minute interval at which seals typically come up for air), not only are there four different cuts, each from a different angle, but in none of them do we see hunter, blowhole and seal all in the same shot.

40 Cited in Ruby (2000), 75.

41 Flaherty (1996), 43.

42 Cited in Ruby (2000), 67.

43 Ruby (2000), 85.

44 See Rouch (I968), 447-55; (I995a), 82. Also Chapter 8 of this book. 